\title{
Confusions in Vitamin D Estimation and Interpretation
}

\author{
Dr. A. Sujatha Rani, MD, Associate Professor \\ Dept. of Biochemistry, Gandhi Medical College, Hyderabad/NTR University of Health Sciences, Andhra \\ Pradesh, India
}

\begin{abstract}
Role of vitamin D in calcium and phosphorous regulation and in bone metabolism is a well known fact and so, was the need for diagnosing vitamin D deficiency in osteoporosis, osteomalacia and fractures. Discovery of the presence of vitamin D receptor in several tissues has lead to several research works to know the effect of vitamin $D$ on these tissues. This has thrown light on previously blind areas. Vitamin D deficiency is known to be present in cancers, infectious diseases, autoimmune disorders,cardiovascular disease type 2 diabetes mellitus. These findings have resulted in increased laboratory requests for vitamin D estimation. This article aims at providing insight 1 . into vitamin $D$ and its metabolic effects, 2.different forms of vitamin D 3.existing methods to estimate vitamin D 4. Selection of the method for estimation, and reference methods for vitamin D estimation, 5. Factors causing variations in vitamin D results, 6. internal and external quality control issues, 7.Interpretation of results.
\end{abstract}

Keywords: 25-hydroxy $D_{3}$, metabolism, $1 \alpha, 25$-hydroxy $D_{3}$, Method of estimation, standards.

\section{Introduction}

Vitamin D is a fat soluble vitamin. The status of vitamin D in humans depends on a) dietary intake of vitamin $\mathrm{D}_{3}$ and $\mathrm{b}$ ) exposure to UV radiation. A diet high in oily fish is a rich source of vitamin $\mathrm{D}$. The skin produces vitamin $\mathrm{D}_{3}$, photochemically from the previtamin $\mathrm{D}$, 7- dehydrocholesterol on exposure to sunlight (or) of artificial UV light[1]. The conjugated double bond system in ring B allows the absorption of light at UV range (290-315 $\mathrm{nm}$ ) resulting in the endogenous production of vitamin $\mathrm{D}_{3}$.

\section{Metabolism:}

Term vitamin $\mathrm{D}$ represents $\mathrm{D}_{2}$ and $\mathrm{D}_{3}$. $\mathrm{D}_{2}$ is produced by ergosterol and $\mathrm{D}_{3}$ by 7-dehydrocholesterol. Vitamin $D_{2}$ and $D_{3}$ from dietary sources are carried by chylomicrons through lymphatic system into the venous circulation. Vitamin $\mathrm{D}$ in the circulation is bound to the vitamin $\mathrm{D}$ binding protein. The vitamin $\mathrm{D}$ is transported to liver, where by the action of 25- hydrxylase enzyme gets metabolized to $25-\mathrm{OH} \mathrm{D}_{3}$ vitamin.25- hydroxyl $\mathrm{D}_{3}$ vitamin is biologically inactive, and it must be converted to $1 \alpha, 25-(\mathrm{OH})_{2}$ D3 in the kidneys for its biological activity. In the kidney $25-\mathrm{OH} \mathrm{D}_{3}$ gets metabolized to its active form by the enzyme $25-\mathrm{OH} \mathrm{D} 1 \alpha$-hydroxylase [2-5]. Another metabolite of $25-\mathrm{OH} \mathrm{D}$ is also formed in the kidney by 24 hydroxylation i.e. $24,25-(\mathrm{OH})_{2} \mathrm{D}_{3}$. These active metabolites are transported to the distal target organs. There they bind to nuclear receptors, vitamin D binding receptor (VDR) and elicit their appropriate biological responses. Over the past several decades the influence of vitamin $\mathrm{D}_{3}$ on various tissues is defined by the tissue distribution of VDR. Research HAS SHOWN THAT $1 \alpha, 25-(\mathrm{OH})_{2} \mathrm{D}_{3}$ initiates the physiologic responses of $\geq 36$ cell types that posess the VDR. Apart from endocrine production by the kidney, i.e. circulating, $1 \alpha, 25-(\mathrm{OH})_{2} \mathrm{D}_{3}$, researchers have found the paracrine production of this steroid hormone in $\geq 10$ extrarenal organs[1].

The structure of vitamin D contains steroid nucleus, cycloperhydrophenanthrene ring. As the mechanism of vitamin D action is similar to the action of steroid hormone, it is called as a hormone apart from vitamin. The hormone similar to steroid hormones generates biological responses both by regulating gene transcription, and by rapidly activating a variety of signal transduction pathways at or near the plasma membrane [6]. $1 \alpha 25(\mathrm{OH})_{2} \mathrm{D}_{3}$ can interact with the vitamin D receptor (VDR) localized in the cell nucleus to generate genomic responses and in caviolae with the plasma membrane VDR to generate rapid responses. Binding of $1 \alpha, 25(\mathrm{OH})_{2} \mathrm{D}_{3}$ to the membrane VDR may result in the activation of one or more second messenger systems, including phospholipase C, protein kinase C ,G-protein coupled receptor or phosphotidylinositol-3kinase. Some of the second messengers such as RAF/MAP kinase, PI- 3,4,5-triphosphate can engage in crosstalk with the nucleus to modulate gene expression. eg. Are pancreatic $\beta$ cell, adipocytes, vascular smooth muscle, intestine, monocytes and osteoblasts.

\section{Regulation}

The renal production of $1 \alpha, 25-(\mathrm{OH})_{2} \mathrm{D}_{3}$ is tightly regulated by plasma parathyroid hormone levels, serum calcium and phosphorous levels [2-5]. Fibroblast growth factor-23, secreted from the bone and small intestine, also play a role in the regulation [7]. Serum calcium, phosphorous, fibroblast growth factor-23, can 
either decrease or increase the renal production of 1, 25- dihydroxyvitamin $\mathrm{D}_{3}$. This hormone is also regulated by negative feed back. It decreases the synthesis and secretion of parathyroid hormone. 1, 25- dihydroxyvitamin $\mathrm{D}$ increases the expression of 25-hydroxy D-24-hydroxylase to catabolise 1,25- dihydroxyvitamin $\mathrm{D}_{3}$ to the water soluble, biologically inactive calcitroic acid which is excreted in bile.1,25-dihydroxyvitamin D increases intestinal calcium absorption in the small intestine by interacting with the vitamin $\mathrm{D}$ receptor-retinoic acid $\mathrm{x}$ receptor complex to enhance the expression of the epithelial calcium channel and calbindin-a calcium binding protein. 1,25- dihydroxy vitamin $\mathrm{D}$ is recognized by its receptor in osteoblasts, which increases the expression of the receptor activator of nuclear factor- $\mathrm{\kappa B}$ ligand on proosteoclasts, which induces proosteoclasts to become mature osteoclasts. Mature osteoclasts remove calcium and phosphorous from the bone, maintaining calcium and phosphorous levels in the blood. In the presence adequate calcium and phosphorous levels, promote the mineralization of the bone.

Without vitamin D only $10-15 \%$ of dietary calcium and $60 \%$ of phosphorous is absorbed $[3,4,5]$. Vitamin D increases efficiency of calcium absorption to $30-40 \%$ and phosphorous absorption to approximately $80 \%$ [3-5,7]. As per a study [4] maximum bone density achieved at $40 \mathrm{ng} / \mathrm{ml}$ of 25 - hydroxyl D in circulating blood below $30 \mathrm{ng} / \mathrm{ml}$ or less there was a significant decrease in intestinal calcium absorption [7]. That was associated with increased parathyroid hormone [8-10]. Parathyroid hormone enhances the tubular re-absorption of calcium and stimulates the kidney to produce 1,25- dihydroxyvitamin D [3-5,11]. Apart from regulation of calcium and phosphorous and bone metabolism, the discovery that most tissues and cells of the body have vitamin $\mathrm{D}$ receptor, and that they can convert the 25 - hydroxyl $\mathrm{D}$ to its active form 1,25-dihydroxyvitamin $\mathrm{D}$ has provided new insights into the function of vitamin D.

ITS role in decreasing the risk of many chronic illnesses including common cancers, autoimmune diseases, cardiovascular diseases, type 2 diabetes mellitus, multiple sclerosis has raised great interest among clinicians to vitamin D. As a result there is tremendous increase in laboratory requests for vitamin D estimation. At this juncture we really need to know, what is the best clinical indicator of vitamin D STATUS, its reliability, how to monitor VITAMIN D metabolites during supplementation of vitamin, and how to interpret these results.

\section{Types of Vitamin D Metabolites}

There are approximately 37 vitamin metabolites that have been isolated [12]. Vitamin $\mathrm{D}_{3}$ is synthesized by UV radiation and dietary sources. Vitamin $\mathrm{D}_{3}$ is produced from previtamin 7-dehydrocholesterol. 1) Vitamin $D_{2}$ is produced from ergosterol. Some studies have established that humans can also metabolise vitamin $\mathrm{D}_{2}$ to 25 - hydroxyl $\mathrm{D}_{2}$ and 1,25-dihydroxy $\mathrm{D}_{2}$ [13]. 2) Vitamin $\mathrm{D}_{3}$ does not have any intrinsic biological activity. It is present as 25 - hydroxy vitamin $\mathrm{D}_{3}$ in the liver, and is biologically inactive. 25-hydroxy vitamin $\mathrm{D}_{3}$ is the major form of vitamin D circulating in the blood compartment. Vitamin D is supplemented either in $\mathrm{D}_{2}$ form or in $\mathrm{D}_{3}$ form. Studies suggest that 25 -hydrxyvitamin $\mathrm{D}_{3}$ levels rise when $\mathrm{D}_{3}$ is supplemented. Vitamin $\mathrm{D}_{2}$ is not that useful in rising $25-(\mathrm{OH}) \mathrm{D}$ as is vitamin $\mathrm{D}_{3}$. Vitamin $\mathrm{D}_{3}$ is more effective than vitamin $\mathrm{D}_{2}$. $[14,15]$. 3)the active form $25-\mathrm{OH} \mathrm{D}_{3}$ is $1 \alpha, 25$-dihydroxy vitamin $\mathrm{D}_{3}$ is produced in the kidney. (Kidney as an endocrine gland) acts as a hormone. There is no reliable method available to estimate $1,25-(\mathrm{OH})_{2} \mathrm{D}_{3}$. 4) 24, 25dihydroxy $\mathrm{D}_{3}$ is also produced in the kidney, and is a hormone. It is a active form. These two hormones are transported through blood to distal target organs. There they are internalized by binding to nuclear receptors or both nuclear and plasma membrane receptors to generate appropriate biological responses [16].

Table.1 Types of vitamin D

\begin{tabular}{|c|c|c|}
\hline Types of Vitamin D & Production in humans & Properties \\
\hline $\begin{array}{l}\text { Vitamin } \mathrm{D}_{3} \text { (Precursor-7- } \\
\text { dehydrocholesterol) } \\
\text { 25-hydroxy } \mathrm{D}_{3}\end{array}$ & In Skin produced by UV rays & $\begin{array}{l}\text { Biologically inactive itself. Does } \\
\text { not bind to VDR. Also supplied } \\
\text { by diet }\end{array}$ \\
\hline Vitamin $\mathrm{D}_{2}$ (Ergosterol) & Not produce in humans & $\begin{array}{l}\text { Supplied through fortified food } \\
\text { are } \mathrm{D}_{2} \text { supplementation }\end{array}$ \\
\hline $1 \alpha, 25$-dihydroxy $\mathrm{D}_{3}$ & $\begin{array}{l}\text { Produced in kidney by } 1 \alpha, 25- \\
\text { hydroxylase }\end{array}$ & $\begin{array}{l}\text { Biologically active form of } \\
\text { vitamin D. It is a steroid } \\
\text { hormone. It acts through VDR }\end{array}$ \\
\hline 24,25-dihydroxy $\mathrm{D}_{3}$ & Also produced in the kidney & Also a steroid hormone \\
\hline
\end{tabular}

\section{1) Competitive vitamin $D$ binding assays}

\section{Commonly Used Methods}

In this naturally occurring vitamin $\mathrm{D}$ binding protein is the ligand binder and titrated 25 - hydroxyl $\mathrm{D}_{3}$ is the tracer [17]. 25-hydroxy $\mathrm{D}$ is taken from serum either by extraction or separated from other lipids by chromatography. Loss of 25-hydroxy $\mathrm{D}$ (endogenous) is compensated by titrating with $25-\mathrm{OH} \mathrm{D}_{3}$ as an internal standard[18]. Advantages are a) the method is equally specific for estimating $25-\mathrm{OH} \mathrm{D}_{3}$ and $25-\mathrm{OH} \mathrm{D}_{2}, \mathrm{~b}$ ) extraction and chromatography methods reduce non specific interferences from other serum constituents. 
Disadvantage is that the procedure is time consuming, needs expensive equipment and disposal of waste poses environmental hazards.

\section{2) Immunoassays}

Antibody was raised against a synthetic vitamin $\mathrm{D}$ analogue coupled to bovine serum albumin. As the structure of $25-\mathrm{OH} \mathrm{D}_{3}$ and $25-\mathrm{OH} \mathrm{D}_{2}$ differ only in their side chains, antibody has equal affinity for both molecules[20].the latest immunoassay method uses ${ }^{125}$ I tracer[19]. In 2004 first chemiluminiscence assay was introduced by Diasorin corporation. In 2007 the methods precision and sensitivity were improved. Manufacturer claims that this technique displaces $25-\mathrm{OH} \mathrm{D}_{3}$ from binding protein completely and consistently. Co-specificity for $25-\mathrm{OH} \mathrm{D}_{3}$ and $25-\mathrm{OH} \mathrm{D}_{2}$ is supported by DEQAS survey in 2008 [21], another study published in 2006[22] did not support the claim.

\section{3) Immunodiagnostic systems (IDS)}

First came out with a radioimmunoassay method. It uses the antibody which is said to have $75 \%$ cross reactivity with 25-hydroxy $\mathrm{D}_{2}$. The other method is enzyme immunoassay. It uses the same antibody. Several studies have been published about the detection of 25- hydroxyl $\mathrm{D}_{2}$ by these methods. Enzyme immunoassays give higher values of 25-hydroxy $\mathrm{D}_{2}$ [23] than those of IDS and Diasorin. Some studies produced comparable results between the assays [21]. The reason for this variation in recovery may be matrix differences. Between complexes[24]. In 2009 IDS came out with a FDA approved chemmiluminiscence method on iSYS automated analyser. The method claims to be specific for 25 - hydroxy $\mathrm{D}_{3}$ and 25 -hydroxy $\mathrm{D}_{2}$. All these methods could not detect 3- epimer of 25- hydroxy D.

Later Roche has developed a chemiluminiscence method for Elecsys-2010/e411 and E-170/Cobas e601 systems. This assay is useful only in detecting 25 -hydroxy $\mathrm{D}_{3}$. An acidic $\mathrm{pH}$ change inactivates the DBP and liberates the bound 25-hydroxy $\mathrm{D}_{3}$. Disadvantage is that it is not suitable to monitor patients supplemented with 25- hydroxyl $\mathrm{D}_{2}$. Rosche uses LC-MS/MS reference method, and a monoclonal antibody.

\section{4) Chromatographic assays}

These are 1) HPLC with UV detection, 2) LC-MS/MS-Liquid chromatography mass spectrometry, usually tandem mass spectrometry has been referred as "gold standard" technique for 25- hydroxy $\mathrm{D}_{3}$ [25]. Both methods can separate individual 25-hydroxy $\mathrm{D}_{3}$ and 25-hydroxy $\mathrm{D}_{2}$. Some authors advise to report total value and others advise to give total 25-hydroxy $\mathrm{D}$ and percentage of 25-hydroxy $\mathrm{D}_{2}[25,26]$. Gas chromatography Mass spectrometry can be regarded as original definitive method for 25-hydroxy D[27]. They are very time consuming, column size is very big, needs lot of space and are seldom used now.

Commercial HPLC and LC-MS/MS kits consisting of reagents, standards and controls are available from chromosystems with trilevel set of human serum based calibrators and controls. ESA has a 25- hydroxyl D method with single calibrator, which is not based on human serum.

\section{Factors Contributing To Variations In Vitamin D Estimations}

These factors pose a challenge to obtain the true value of patient's vitamin D levels [28]. Interferences in patient samples can potentially affect the vitamin D values. Different assay methods can also attribute to different vitamin D values. Potentially harmful factors that could contribute to the variations in 25- hydroxy D values are,

\section{Preanalytical}

Preanalytical issues are concerned with sample stability. Vitamin D and its metabolites are unstable compounds, on exposure to UV light, they are rapidly degraded. 25-OH D and 1,25- dihydroxy viyamin D are extremely stable compounds, as they are bound to vitamin D binding protein (DBP). These samples are opaque to UV radiation. [25] and they can be stored for days at room temperature with out any significant change in $25-\mathrm{OH}$ D concentration[29,30]. Repeated freezing and thawing also has no significant effect on serum concentrations of 25- OH D[31]. Blood collection tubes-majority of laboratories collect blood either in anticoagulant or gel tubes. Study done by Lensmayer G.L et al [32] said that gels have adverse effects on some steroid assays, including HPLC methods for 25-OH D. Another study done by DEQAS [33], said immunoassays were not effected by gels, but about one third of HPLC and few LC-MS/MS users reported spuriously high results. EDTA mixed samples gave low values in immunoassay methods, but HPLC methods were un affected. Serum from Sarstedt Monovette tubes were found to give significantly raised levels in LCMS/MS assays. Hence blood for 25-OH D measurement is probably best collected into plain tubes without anticoagulants or gels. 


\section{Analytical}

Analytical variations are mainly due to sample interference accuracy of 25-OH D depends on the blood concentrations of vitamin D binding protein [34]. Variations also occur due to the presence of the human anti animal antibodies (HIAA) [35].

\section{Assay characteristics}

Among assay characteristics influencing the result are, the first problem which will change the assay is the lipophilic nature of the molecule makes the assay prove to interference from other lipids, like lipoproteins (matrix effects) extraction assays such as competitive protein binding assays are effected by matrix-effects [17]. But as matrix effects are unpredictable, they may vary from sample to sample [36,37]. There are always method related differences in individual samples. A common problem with non-extraction assays is the analyte has to be completely displaced from its binding protein completeness of vitamin D dissociation from DBP will determine the assay.

The second problem common to extraction and non-extraction assay is the preparation of standards. Stock standards are calibrated at AMax i.e. $265 \mathrm{~nm}$. Purity of the standard is checked by calculating the ratio AMax: AMin which should be 1.5. If the ratio is lower than 1.5, the standard should be repurified (or) replaced [38].

Commercial working standards are often described as human serum based. To serum stock standard is added. From the serum endogenous $25-\mathrm{OH} \mathrm{D}$ is removed by activated charcoal at acidic $\mathrm{pH}$. Both of them create matrix effects which brings variations in assays [24].

The third problem is invitro addition of 25 -hydroxy vitamin D results in erroneous values by nonextraction assays. There is incomplete disruption of vitamin D binding protein from 25-hydroxy vitamin D. Almost all methods face standardization problems, because different predicates used by different manufacturers and lack of standard reference procedure and reference materials.

To improve the situation one study [22] proposed to develop-in-house reference method to provide an accuracy based for other testing methods. To take the assay uncertainty into consideration, while setting up vitamin D cut of value among different assays [24].

\section{Post analytical}

Post analytical factors are mostly to do with interpretation factors, and is discussed in section VII.

\section{Selection Of Appropriate Method}

Method choice depends on several factors 1) Sample throughput 2) Expertise of staff 3) Sample origin. i.e. whether to estimate 25 -hydroxy vitamin $\mathrm{D}_{2}$ (or) 25-hydroxy vitamin $\mathrm{D}_{3}$ one has to look into which vitamin is being supplemented i.e. $25-\mathrm{OH} \mathrm{D}_{2}$ (or) $25-\mathrm{OH} \mathrm{D}_{3}$. Confusion can arise when a patient supplemented with vitamin $\mathrm{D}_{2}$ is monitored by a method to measure only 25-hydroxy vitamin $\mathrm{D}_{3}$ [39]. Occasional neonatal samples for 3-epi-25-OH D can be sent to a specialist centre for analysis. When small numbers of laboratory request for 25-hydroxy vitamin D, a good choice of method would be either HPLC (or) LC-MS/MS. Where there are more laboratory requests a dedicated instrument for 25-hydroxy vitamin D estimation would be appropriate. For long term vitamin D studies, continuity of quality of an assay is required. Immunoassays are affected by occasional changes of antibody (or) reformulation of reagents. This would make interpretation of studies difficult, as it was by NHANES [40].

\section{Type Of Vitamin D To Be Estimated}

Blood concentration of total 25-hydroxy vitamin $\mathrm{D}$ (sum of 25-hydroxy vitamin $\mathrm{D}_{2}$ and 25-hydroxy vitamin $\mathrm{D}_{3}$ ) is the established biomarker to determine patient's vitamin D status [41]. Vitamin D3 is mainly produce in skin through sunlight exposure. Vitamin D2 is found in certain types of natural foods and fortified foods. Both forms of vitamin D can be obtained from vitamin D supplements [41]. Both forms of vitamin D are metabolized to 25-OH D in the liver and further to 1,25-dihydroxy vitamin D in the kidney, and both forms exhibit the same biological activities.

To monitor the effects of supplements it is crucial that the 25-hydroxy vitamin D assay used recognized both forms of vitamin D to accurately reflect patient's vitamin D status. Many vitamin D experts recommend the used of vitamin $\mathrm{D}$ assays with equal detection of vitamin $\mathrm{D}_{2}$ and $\mathrm{D}_{3}(42)$.

\section{Interpretation Of Vitamin D Results}

Each laboratory provides reference interval to interpret results. These reference intervals vary based on based on local population, type of analytical method used. The reference ranges usually include $95 \%$ of the results of the population. For vitamin D obtaining reference intervals from local population does not work as vitamin D deficiency is worldwide[43]. Hence majority of such population derived reference ranges will be 
low, which leads to under diagnosis of vitamin D deficiency. One such large population based study [44] gave 25- OH D range as 25-137 nmol /L. Other study [45] suggest a reference range of 100- $175 \mathrm{nmol} / \mathrm{L}$. Several studies have been done [2-5,11] to confirm the presence vitamin D receptors in brain, prostate, breast and colon tissues, and also immune cells. These tissues respond to 1,25- dihydroxy vitamin $\mathrm{D}$, the active form of vitamin D. Some of these tissues and cells express the enzyme 25-hydroxy vitamin D-1 $\alpha$-hydroxylase[2-4,11]. 1, 25- dihydroxy vitamin D controls more than 200 genes, that includes genes responsible for the regulation of cellular proliferation, differentiation, apoptosis, and angiogenesis[2,3,50]. Due to these varied actions of 1,25dihydroxy vitamin D , defining reference ranges for $25 \mathrm{OH} \mathrm{D}$ in each group of patients, might assist the clinician to supplement vitamin D in appropriate doses, to prevent vitamin D toxicity. Standing committee of European Doctors(CPME)[46] concluded that several diseases including colon cancer, infections, multiple sclerosis, type 1 and 2 diabetes are more prevalent in subjects with $25-\mathrm{OH} \mathrm{D}$ levels below $50 \mathrm{nmol} / \mathrm{L}$.

Several studies have proved that results given by different methods are not comparable $[32,37,47]$ making the interpretation all the more difficult. Survey conducted by DEQAS showed most major methods give results within about $10 \%$ of the consensus mean. Two possible solutions to these problems have been proposed [48], though entirely not satisfactory - 1) an arithmetical correction to be made to LC-MS/MS positive biased results. But the use of single correction factor for all results would be inappriate. 2) Other Diasorin based radioimmunoassay should be adjusted to correct their negative bias.

This variability of results among laboratories using the same method, the reference range problem can be adjusted based on published method comparisons (eg. DEQAS).This should satisfy clinicians, who would wish to know whether their patient should be given vitamin D supplementation or not. There are also interpretation problems when a lab changes the method for vitamin D estimation. If the lab converts assay LCMS/MS to fully automated 25-OH D immunoassay, there should not be a major change in the total 25-OH D value, as the previous LC-MS/MS also detected both vitamin $\mathrm{D}_{2}$ and vitamin $\mathrm{D}_{3}$.

The change comes only when converting from another immunoassay with partial $\mathrm{D}_{2}$ detection. When no $\mathrm{D}_{2}$ supplements are taken, there will not be much changes in the total 25- hydroxy vitamin D by fully automated method, which reflects the true vitamin D levels.

Table.2 Circulating concentrations of 25-hydroxyvitamin D [25(OH)D]

\begin{tabular}{|l|l|l|}
\hline \multicolumn{1}{|c|}{ Serum 25(OH)D range2 } & \multicolumn{1}{c|}{ Vitamin D nutritional status } & \multicolumn{1}{c|}{ Reference } \\
\hline$>75 \mathrm{nmol} / \mathrm{L}(>30 \mathrm{ng} / \mathrm{mL})$ & Sufficiency & {$[52]$} \\
$>50 \mathrm{nmol} / \mathrm{L}(>20 \mathrm{ng} / \mathrm{mL})$ & Sufficiency & {$[53,54]$} \\
$30-50 \mathrm{nmol} / \mathrm{L}(12-20 \mathrm{ng} / \mathrm{mL})$ & Insufficiency & {$[55]$} \\
$12-30 \mathrm{nmol} / \mathrm{L}(5-12 \mathrm{ng} / \mathrm{mL})$ & Deficiency & {$[53]$} \\
$<12 \mathrm{nmol} / \mathrm{L}(<5 \mathrm{ng} / \mathrm{mL}) 2$ & Severe deficiency & {$[53]$} \\
\hline
\end{tabular}

Table.3 Vitamin D Status in Relation to 25(OH)-D Levels in children's[56]

\begin{tabular}{|l|l|}
\hline \multicolumn{1}{|c|}{ Vitamin D Status } & \multicolumn{1}{|c|}{$25(\mathrm{OH})-\mathrm{D}$ Level, $\mathrm{nmol} / \mathrm{L}(\mathrm{ng} / \mathrm{mL})$} \\
\hline Severe deficiency & $\leq 12.5(5)$ \\
Deficiency & $\leq 37.5(15)$ \\
Insufficiency & $37.5-50.0(15-20)$ \\
Sufficiency & $50-250(20-100) \mathrm{a}$ \\
Excess & $>250(100) \mathrm{b}$ \\
Intoxication & $>375(150) 104$ \\
\hline
\end{tabular}

\section{Standardisation And External Quality Assessment Of Vitamin D}

The main reason for variations in vitamin $\mathrm{D}$ values reported by different methods and different laboratories is variations in their standards. This stresses upon the need to standardize 25- hydroxy vitamin D assays to provide accurate measurement and reliable patient care. One such organization is DEQAS in U.K. It distributes serum samples to participants at a quarterly basis and statistically analyses submitted results to generate all lab trimmed means(ALTM)[51] To which each participant can compare their own method (www.deqas.org).With this measure interlaboratory imprecision (\%CV) is reduced from $>30 \%$ in 1995 to $15 \%$ in 2011 ,although the ideal \% CV should be $<10 \%$.therefore there is a need to develop reference materials and a reference measurement procedure against which both chromatographic and immunoassays could be standardized. In 2009 National Institute of Standards and Technology (NIST) introduced reference materials SRM 972[49]. These reference materials helped to reduce variations in DEQAS samples.

These reference materials are spiked with exogenous metabolites (or) diluted with equine serum, the sample matrix is not suitable for many immunoassays [49]. Search for new reference materials that suit both LC-MS/MS and immunoassays is on.

A reference LC-MS/MS procedure is developed by NIST and university of Ghent .Clinical serum samples are available for labs to calibrate their current assay against the reference methods. Quarterly samples 
for EQAS can be used. The goal should be bias $\pm 5 \%$ and imprecision $\leq 10 \%$ respectively. (www.cdc.gov/labstandards /).

\section{Conclusions}

1) The knowledge of vitamin $\mathrm{D}_{3}$ as a vitamin and as a hormone are very essential to assess the importance of $1 \alpha, 25$-dihydroxy $\mathrm{D}_{3}$ in bone metabolism as well as in the metabolism of extra skeletal tissues through VDR.

2) The sources of vitamin $D_{3}$ emphasizes on exposure to UV rays for its synthesis. At the same time over exposure to UV rays can cause melanomas, thus the supplementation of vitamin $\mathrm{D}_{3}$ or $\mathrm{D}_{2}$ either as fortified foods or as medication gains importance. At this onset vitamin $\mathrm{D}_{3}$ estimation becomes the centre point for monitoring vitamin $\mathrm{D}_{3}$ levels or to diagnose the deficiency of vitamin $\mathrm{D}_{3}$ in various diseases.

3) The estimation of vitamin $D_{3}$ is effected by several factors such as pre-analytical which mainly a concerned with sample stability and sample interference. The analytical variations depend on the concentration of vitamin $\mathrm{D}$ binding protein, and how vitamin $\mathrm{D}_{3}$ can be dislodged from its binding protein. Apart from this vitamin $\mathrm{D}_{3}$ results also show variations due to difference in internal standards, matrix effects, lack of reference methods and low availability of EQAS for vitamin D.

4) The best method for estimation of vitamin $D_{3}$ is the method which can estimate both vitamin $D_{2}$ levels and vitamin $\mathrm{D}_{3}$ levels separately. There is still a lot of scope to research into newer methods and finding a way for uniform vitamin $\mathrm{D}_{3}$ values between laboratories.

5) The interpretation of vitamin $D_{3}$ might need different cut off values when it comes to the vitamin $D$ deficiency in extra skeletal tissues. Such as cancers autoimmune disorders, diabetes, infections etc. This provides a vide scope for research into vitamin D cut off ranges for each disease.

\section{References}

[1]. Anthony W Norman From Vitamin D to hormone D: fundamentals of the vitamin D endocrine system essential for good health ${ }^{1-4}$ Am J Clin Nutr 2008;88(suppl):491S-9S.

[2]. Holick MF. Resurrection of vitamin D deficiency and rickets. J Clin Invest 2006; 116:2062-72.

[3]. Holick MF, Garabedian M. Vitamin D: photobiology, metabolism, mechanism of action, and clinical applications. In: Favus MJ, ed. Primer on the metabolic bone diseases and disorders of mineral metab-olism. 6th ed. Washington, DC: American Society for Bone and Mineral Research, 2006:129-37.

[4]. Bouillon R. Vitamin D: from photosynthesis, metabolism, and action to clinical applications. In: DeGroot LJ, Jameson JL, eds. Endocrinology. Philadelphia: W.B. Saunders, 2001:1009-28.

[5]. DeLuca HF. Overview of general physiologic features and functions of vitamin D. Am J Clin Nutr 2004; 80: Suppl: 1689S-696S

[6]. Norman AW, Mizwicki MT, Norman DPG. Steroid hormone rapid actions, membrane receptors and a conformational ensemble model. Nat Rev Drug Discov 2004;3:27-41.

[7]. Hruska KA. Hyperphosphatemia and hypophosphatemia. In: Favus, MJ, ed. Primer on the metabolic bone diseases and disorders of mineral metabolism. 6thed. Washington, DC: American Society for Bone and Mineral Research, 2006:233-42.

[8]. Thomas KK, Lloyd-Jones DM, Thadhani RI, et al. Hypovitaminosis D in medical inpatients. N Engl J Med 1998;338:777-83.

[9]. Chapuy MC, Preziosi P, Maamer M, et al. Prevalence of vitamin D insufficiency in an adult normal population. Osteoporos Int 1997;7:439-43.

[10]. Holick MF, Siris ES, Binkley N, et al. Prevalence of vitamin D inadequacy among postmenopausal North American women receiving osteoporosis therapy. J Clin Endocrinol Metab 2005;90:3215-24.

[11]. Dusso AS, Brown AJ, Slatopolsky E. Vitamin D. Am J Physiol Renal Physiol 2005;289:F8-F28.

[12]. Bouillon R, Okamura WH, Norman AW. Structure-function relationships in the vitamin D endocrine system. Endocr Rev 1995; $16: 200-57$.

[13]. Horst RL, Reinhardt TA, Reddy GS. Vitamin D metabolism. In: Feldman D, Pike JW, Glorieux FH, eds. Vitamin D. San Diego, CA: Elsevier Academic Press 2005:15-36

[14]. Trang H, Cole DE, Rubin LA, Pierratos A, Siu S, Vieth R. Evidence that vitamin $\mathrm{D}_{3}$ increases serum 25-hydroxyvitain D more efficiently than does vitamin $\mathrm{D}_{2}$. Am J Clin Nutr 1998;68:854-8.

[15]. Armas LAG, Hollis BW, Heaney RP. Vitamin D2 is much less effective than vitamin $\mathrm{D}_{3}$ in humans. J Clin Endocrinol Metab 2004;89:5387-91.

[16]. Bishop JE, Collins ED, Okamura WH, Norman AW. Profile of ligand specificity of the vitamin D binding protein for 1 $\alpha, 25(\mathrm{OH}) 2-$ vitamin D3 and its analogs. J Bone Miner Res 1994;9:1277-88.

[17]. Haddad JG, Chyu KJ. Competitive protein-binding radioassay for 25-hydroxycholecalciferol. J Clin Endocrinol Metab 1971; 33: 554-7.

[18]. Carter GD, Jones JC, Berry JL. The anomalous behaviour of exogenous 25-hydroxy vitamin D in competitive binding assays. J Steroid Biochem Mol Biol 2007; 103:480-2.

[19]. Hollis BW, Kamerud JQ, Selvaag SR, Lorenz JD, Napoli JL. Determination of vitamin D status by radioimmunoassay with an ${ }^{125}$ Ilabelled tracer. Clin Chem 1993; 39: 529-53.

[20]. Hollis BW, Napoli JL. Improved radioimmunoassay for vitamin D and its used in assessing vitamin D status. Clin Chem 1985; 31 : $1815-9$.

[21]. Vitamin D External Quality Assessment Scheme (DEQAS) 25-OHD report, January 2008 distribution. London, UK: Charing Cross Hospital.

[22]. Glendenning P, Noble JM, Taranto M, et al. Current assays overestimate 25-hydroxyvitamin $\mathrm{D}_{3}$ and underestimate 25hydroxyvitamin $\mathrm{D}_{2}$ compared with HPLC: need for assay-specific decision limits and metabolite-specific assays. Ann Clin Biochem 2006;43: 23-30.

[23]. Vitamin D External Quality Assessment Scheme (DEQAS) 25-OHD report, January 2004 distribution. London, UK: Charing Cross Hospital. 
[24]. Graham D. Carter; Accuracy of 25-Hydroxyvitamin D assays: Confronting the Issues, Current Drug Targets, 2011,12,19-28.

[25]. Hollis B. Measuring 25-hydroxyvitamin D in a clinical environment: challenges and needs. Am J Clin Nutr 2008; 88(suppl): 507S$10 \mathrm{~S}$.

[26]. Binkley N, Drezner MK, Hollis BW. Laboratory reporting of 25-hydroxyvitamin D results: potential for clinical misinterpretation. Clin Chem 2006; 52: 2124-5.

[27]. Wootten AM, Improving the measurement of 25-hydroxyvitamin D. Clin Biochem Rev 2005; 26: 33-6.

[28]. Farrell CJL, et al, State of the Art Vitamin D assays: A comparison of Automated immunoassays with liquid chromatographyTandem Mass Spectrometry Methods, Clin Chem 2012, 58:3.

[29]. Lissner D, Mason RS, Posen S. Stability of vitamin D metabolites in human blood serum and plasma. Clin Chem 1981; $27: 773-4$.

[30]. Berry JL, Selby PL, Davies M, Martin J. Observations from the UK Supra-Regional Assay Service laboratory for the measurement of vitamin D metabolites. J Steroid Biochem Mol Biol 2007; 103: 477-9.

[31]. Antoniucci DM, Black DM, Sellmeyer DE. Serum 25-hydroxyvitamin D is unaffected by multiple freeze-thaw cycles. Clin Chem 2004; 51: 258-60.

[32]. Lensmeyer GL, Wiebe DA, Binkley B, Drezner MK. HPLC Method for 25-hydroxyvitamin D measurement: comparison with contemporary assay. Clin Chem 2006; 52: 1120-26.

[33]. Vitamin D External Quality Assessment Scheme (DEQAS) 25-OHD report, July 2009 distribution. London, UK: Charing Cross Hospital.

[34]. Heijboer AC, et al, Accuracy of 6 Routine 25-hydroxyvitamin D assays; Influence of vitamin D binding protein concentration, Clin Chem, 2012, 58:3.

[35]. Cavalier E, et al, Human anti-animal interference in DiaSorin Liaison total 25(OH) vitamin D assay: towards the end of a strange story? Clinca Chimica Acta, 2012, 413:527.

[36]. Maunsell Z, Wright DJ, Rainbow SJ. Routine isotope-dilution liquid chromatography-tandem mass spectrometry assay for simultaneous measurement of the 25-hydroxy metabolites of vitamins $\mathrm{D}_{2}$ and $\mathrm{D}_{3}$. Clin Chem 2005; 51: $1683-90$.

[37]. Roth HJ, Schmidt-Gayk H, Weber H, Niederau C. Accuracy and clinical implications of seven 25-hydroxyvitamin D methods compared with liquid chromatography-tandem mass spectrometry as a reference. Ann Clin Biochem 2008; 45: 153-9.

[38]. Horst RL, Reinhardt TA, Hollis BW. Improved methodology for the analysis of plasma vitamin D metabolites. Kidney Int Suppt 1990; 29: S28-35.

[39]. Cavalier E, Wallace AM, Knox S, Mistretta V, Cormier C, Souberbielle J-C. Serum vitamin D measurement may not reflect what you give to your patients. JBMR 2008; 23: 1864-5.

[40]. Scheicher R, Pfeiffer CM. Vitamin D testing: how will we get it right? Clinical Laboratory News 2009; $35: 1-7$.

[41]. Holick MF, et al, Evaluation, Treatment, and Prevention of Vitamin D Deficiency: an endocrine Society Clinical Practice Guideline, J Clin Endocrin Metab. 2011-96(7): 1911-3.

[42]. Kleerekoper M, et al, Clinical applications for vitamin D assays: what is known and what is wished for. Clin Chem. $2011 ; 57: 1227$.

[43]. Hollick MF, Chen TC. Vitamin D deficiency: a worldwide problem with health consequences. Am J Clin Nutr 2008; 87: 1080 S-6.

[44]. Norman AW. From vitamin D to hormone D: fundamentals of the vitamin D endocrine system essential for good health. AJCN 2008; 88(suppl): 507S-10S.

[45]. Cannell JJ, Hollis BW. Use of vitamin D in clinical practice. Altern Med Rev 2008; 13: 619.

[46]. Vitamin D nutritional policy in Europe. CPME 2009/179 Final EN.

[47]. Binkley N, Krueger D, Cowgill CS, et al. Assay variation confounds the diagnosis of hypovitaminosis D: a call for standardization. J Clin Endocrinol Metab 2004; 89: 3152-7.

[48]. Hollis BW. Assessment of vitamin D status and definition of a normal circulating range of 25-hydroxyvitamin D. Curr Opin Endocrinol Diabetes Obes 2008; 15: 489-94.

[49]. Carter GD, et al, 25-Hydroxyvitamin D: A difficult Analyte, Clin Chem, 2012, 58:3.

[50]. Nagpal S, Na S, Rathnachalam R. Noncalcemic actions of vitamin d receptor ligands. Endocr Rev 2005;26:662-87.

[51]. Healey MJR. Outliers in clinical chemistry quality control schemes. Clin Chem 1979;25:675-7.

[52]. Vieth R, Bischoff-Ferrari H, Boucher BJ, et al. The urgent need to recommend an intake of vitamin D that is effective. Am J Clin Nutr 2007;85:649-50.

[53]. Need AG. Bone resorption markers in vitamin D insufficiency. Clin Chim Acta 2006;368:48 -52.

[54]. Norman AW, Bouillon R, Whiting SJ, Vieth R, Lips P. 13th Workshop consensus for vitamin D nutritional guidelines. J Steroid Biochem Mol Biol 2007; 103:204 -5.

[55]. Fournier A, Fardellone P, Achard JM, et al. Importance of vitamin D repletion in uraemia. Nephrol Dial Transplant 1999;14:819 23.

[56]. Vitamin D Deficiency in Children and Its Management: Review of Current Knowledge and Recommendations, Madhusmita Misra, Daniele et al, American Academy of Paediatrics, Pediatric Endocrine Society, Pediatrics 2008;122;398-417. 